W imieniu komitetu organizacyjnego głos zabrała Anne-Laure Zwilling (EUREL), która podsumowała całość obrad nawiązując do poszczególnych referatów. Wyraziła uznanie dla współorganizatorów (KUL) za znakomicie przygotowaną konferencję oraz podziękowała wszystkim uczestnikom za obecność oraz aktywny udział w obradach.

Mgr Kacper Chołody Wydziat Prawa, Prawa Kanonicznego i Administracji Katolicki Uniwersytet Lubelski Jana Pawła II

\title{
Międzynarodowa konferencja naukowa pt. Obecność krzyża w przestrzeni publicznej państw europejskich, Lublin, 12-13 listopada 2014 r.
}

W dniach 12-13 listopada 2014 r. w Lublinie odbyła się Międzynarodowa konferencja naukowa pt. Obecność krzyża w przestrzeni publicznej państw europejskich. Organizatorami spotkania byli: Katedra Prawa Wyznaniowego na Wydziale Prawa, Prawa Kanonicznego i Administracji Katolickiego Uniwersytetu Lubelskiego Jana Pawła II oraz Polski Instytut Katolicki „Sursum Corda” z siedzibą w Gdańsku. Miejscem konferencji była Aula im. Stefana Kardynała Wyszyńskiego na Katolickim Uniwersytecie Lubelskim Jana Pawła II w Lublinie.

Impulsem do podjęcia międzynarodowego dyskursu dotyczącego obecności krzyża w sferze publicznej było nie tylko rozstrzygnięcie kwestii obecności tego symbolu przez Europejski Trybunał Praw Człowieka w sprawie Lautsi przeciwko Włochom, ale przede wszystkim poddanie pod publiczną debatę zasadności obecności krzyża w polskim parlamencie i innych instytucjach i urzędach w Polsce, co stało się także przedmiotem rozstrzygnięć polskich sądów.

Otwarcia konferencji i powitania zarówno prelegentów, jak i przybyłych gości dokonał Dziekan Wydziału Prawa, Prawa Kanonicznego i Administracji, ks. dr hab. Piotr Stanisz, prof. KUL, który podkreślił doniosłe znaczenie aspektu prawno-porównawczego dla zrozumienia i rozstrzygania spraw z zakresu wolności religijnej. Stąd tak szerokie gremium znawców tematyki relacji państwa z kościołami i innymi związ- 
kami wyznaniowymi oraz tematyki wolności religijnej. Odwołując się do rozstrzygnięcia Wielkiej Izby Europejskiego Trybunału Praw Człowieka z 18 marca 2011 r., naświetlił okoliczności, w jakich doszło do wszczęcia sporu dotyczącego obecności krzyża w przestrzeni publicznej w Polsce.

Następnie głos przejął ks. apb prof. dr hab. Stanisław Budzik - Metropolita Lubelski, Wielki Kanclerz KUL, który wyrażając słowa wdzięczności za zorganizowanie konferencji przedstawił znaczenie krzyża zarówno dla pierwszych chrześcijan, jak i dla narodu polskiego. Ksiądz Arcybiskup przywołał także słowa św. Jana Pawła II, który dziękował, że krzyż przypominający zarówno o polskich korzeniach, jak i o miłości Boga do człowieka, po latach walki z religią katolicką, powrócił do polskich szkół i szpitali.

Do aktu inauguracji konferencji przyłączył się również ks. prof. dr hab. Antoni Dębiński - Rektor KUL, który podkreślił aktualność i trafność tematyki spotkania. Przywołał także Edykt Mediolański, który nie tylko stanowił podstawę wolności religijnej, ale niejako wprowadził krzyż do przestrzeni publicznej.

Jako ostatni spośród przedstawicieli organizatorów zabrał głos Senator RP Grzegorz Bierecki (Fundator i Członek Rady Polskiego Instytutu Katolickiego „Sursum Corda”), który podkreślił, że jednym z głównych celów działania Instytutu jest wspieranie badań naukowych nad zmianami prawnymi w Polsce oraz wspieranie takich wydarzeń, jakim jest zorganizowana konferencja. Przedstawiając tło polityczne zawieszenia krzyża w sali obrad Sejmu w nocy z 19 na 20 października 1997 r., sporo uwagi poświęcił także sprawom obrazy uczuć religijnych, oraz polskiemu ustawodawstwu z zakresu ochrony przedmiotów i miejsc kultu religijnego.

Merytoryczna część konferencji została podzielona na cztery sesje. Pierwsza sesja dotyczyła perspektywy ogólnoeuropejskiej, tj. spojrzenia na obecność krzyża z punktu widzenia orzecznictwa Europejskiego Trybunału Praw Człowieka oraz prawa europejskiego. Sesji przewodniczył ks. prof. dr hab. Henryk Misztal (KUL).

Pierwszy referat, pt. Obecność krzyża w przestrzeni publicznej z perspektywy Europejskiego Trybunału Praw Człowieka, wygłosił prof. dr Rik Torfs - Rektor KU Leuven (Catholic University of Leuven). Prelegent bazując na dwóch wyrokach w sprawie Lautsi przeciwko Włochom skupił się na podstawowej hipotezie: czy krzyż powieszony na ścianie sali lekcyjnej narusza neutralny charakter edukacji? Mając na uwadze uznanie przez Europejski Trybunał Praw Człowieka krzyża za symbol pasywny oraz przyzna- 
nie państwom tzw. marginesu uznaniowości przy interpretacji wolności sumienia i religii, autor dokonał analizy zagadnień dotyczących m.in. roli orzecznictwa w zakresie rozstrzygania w sprawach dotyczących wolności religijnej i roli symboli religijnych dla religii. Dokonał również interpretacji zasady neutralności, rozważając ją w kontekście wolności od symboli.

Drugi referat, pt. Krzyż $i$ inne symbole religijne $w$ prawie europejskim. Uwagi na tle przystapienia Unii Europejskiej do Europejskiej Konwencji Praw Człowieka, wygłosił dr Michał Rynkowski (Programme Officer, European Commission). Autor referatu wskazał, że prawo Unii Europejskiej jako prawo traktatowe, odnoszące się głównie do sfery gospodarczej, nie reguluje spraw z zakresu prawa wyznaniowego, pozostawiając tę sferę państwom członkowskim. W bezpośrednim odniesieniu do symboli religijnych pozostają jedynie przepisy odmawiające ochrony znakom handlowym wykorzystującym symbolikę religijną oraz przepisy celne dotyczące obrotu przedmiotami kultu religijnego. Szansę na zmianę tej sytuacji autor referatu upatruje w planowanym przystąpieniu Unii Europejskiej do Europejskiej Konwencji Praw Człowieka. Spowoduje to możliwość występowania w sprawach z zakresu wolności sumienia i wyznania przed Europejskim Trybunałem Sprawiedliwości bez konieczności skarżenia poszczególnych państw. Dobrą stroną takiego rozwiązania będzie uproszczenie postępowania, a także stworzenie nowego „płaszcza ochronnego” dla praw człowieka.

Sesja druga i trzecia zostały poświęcone rozwiązaniom dotyczącym obecności krzyża w przestrzeni publicznej stosowanym w niektórych państwach europejskich. Sesji trzeciej przewodniczył ks. dr hab. Tadeusz Stanisławski (KUL). Jak wynikało z poszczególnych prezentacji, w każdym z omówionych państw europejskich symbolika religijna odgrywa znaczącą rolę, a symbole religijne $\mathrm{w}$ różnym zakresie są obecne w przestrzeni publicznej. Perspektywa włoska, którą przedstawił prof. Giorgio Feliciani (Facoltà di Diritto Canonico San Pio X, Venezia) pokazuje, że obowiązujące we Włoszech ustawodawstwo reguluje obecność krzyży wyłącznie w odniesieniu do szkół publicznych w dekrecie królewskim z 1926 r. Pozostałe przepisy w tym zakresie są dość ogólne i pozwalają na regulowanie tej kwestii poprzez poszczególne regiony Włoch, przez co także orzecznictwo sądowo-administracyjne pozostaje niejednolite. Prelegent rozważał zasadność obecności symboliki religijnej w sferze publicznej biorąc za punkt odniesienia właściwe rozumienie świeckości państwa oraz dokonał analizy tego pojęcia. Ponadto odwołał się do sondaży świadczą- 
cych o zdecydowanym poparciu obecności krzyża w przestrzeni publicznej przez włoskie społeczeństwo.

Kolejne wystąpienie dotyczyło rozwiązań hiszpańskich, które przedstawił prof. dr Javier Martinez-Torron (Universidad Complutense de Madrid, Facultad de Derecho). Prelegent przypomniał, że Hiszpania od 1971 r. nie jest już państwem wyznaniowym, a obowiązujące regulacje prawne związane $\mathrm{z}$ aspektami religijnymi odnoszą się do służb mundurowych i wojska i dotyczą ich uczestnictwa w kulcie publicznym. W Hiszpanii przysługuje także prawo do składania przysięgi religijnej przy obejmowaniu urzędów publicznych. Kwestionowanie obecności krzyża w hiszpańskich urzędach i instytucjach publicznych jest podważane głównie za przyczyną prężnie działających organizacji ateistycznych, które w walce z przejawami religijności w życiu publicznym, powołują się na neutralność państwa i naruszenie wolności sumienia i religii osób bezwyznaniowych oraz ateistów. W związku z tym prelegent podjął się analizy zasady neutralności państwa, która jego zdaniem nie może być rozumiana jako odseparowanie państwa od religii, gdyż Konstytucja Hiszpanii zakłada współdziałanie państwa i kościoła. Ponadto neutralność państwa nie może prowadzić do ograniczania praw człowieka, do których należy wolność religijna.

Trzeci wykład, przedstawiający rozwiązania stosowane w Niemczech, wygłosił prof. dr Stephan Haering (Ludwig-Maximilins-Universität München). Prelegent przedstawił system relacji państwo - kościół w Niemczech w oparciu o konstytucyjną zasadę świeckości i neutralności państwa. Autor referatu przywołał przy tym obowiązek współpracy tych podmiotów, którego istota sprowadza się do rozstrzygania spornych kwestii, takich jak obecność krzyża, w drodze porozumienia obu stron. Przytaczane orzecznictwo z jednej strony wskazywało na prawo do niewyznawania żadnej religii, z drugiej natomiast na prawo do decydowania o obecności symboli religijnych przez osoby, których dotyczy sprawa, przy zachowaniu wolności religijnej obu stron, podkreślając jednocześnie znaczenie kulturowe krucyfiksu. Podsumowując obecną sytuację w Niemczech, prelegent, pomimo braku zakazu wieszania krzyży w Niemczech, wyraził zaniepokojenie możliwością zepchnięcia religii do sfery prywatnej.

Następnie głos zabrał prof. Mark Hill QC (Cardiff University, Carddiff Law School), przedstawiając brytyjskie spojrzenie na problematykę obecności krzyża w przestrzeni publicznej. Rozpoczynając wywód od znaczenia krucyfiksu - najpierw jako narzędzia egzekucji, a następnie jako 
głębokiego duchowego symbolu chrześcijaństwa, dokonał krytyki wyroku Wielkiej Izby Europejskiego Trybunału Praw Człowieka z 2011 r. Zdaniem prelegenta, Wielka Izba Europejskiego Trybunału Praw Człowieka dokonała zaprzeczenia głęboko religijnego znaczenia krzyża w celu pozostawienia go w sali szkolnej. W odniesieniu do Wielkiej Brytanii podkreślił, że symbole religijne są obecne w brytyjskiej przestrzeni publicznej i nie jest to kwestią problematyczną. W przytoczonej sprawie Eweida i Chaplin przeciwko Zjednoczonemu Królestwu skarżące powoływały się pierwotnie na przepisy antydyskryminacyjne z zakresu prawa pracy, a nie naruszenie ich wolności sumienia i wyznania. Wielka Brytania dopuszcza obecność religii w życiu publicznym, kiedy jest ku temu uzasadniony powód. Przejawem tej zasady jest chociażby obecność przedstawicieli władz kościelnych w parlamencie, możliwość prowadzenia szkół przez organizacje religijne, a przede wszystkim jedność personalna głowy państwa i głowy kościoła w Wielkiej Brytanii.

Ostatni wykład sesji drugiej, dotyczący rozwiązań francuskich, wygłosił prof. Philippe Nélidoff (l'Université Toulouse Capitole), którego zdaniem na obecność symboli religijnych w danym kraju należy patrzeć przez pryzmat historii tego kraju i przewrotów, jakie w danym kraju się dokonały. Należy mieć także na uwadze konieczność zachowania pokoju w społeczeństwie wielokulturowym i wieloreligijnym. Prelegent odwołał się także do zasady świeckości państwa, która została określona wprost w konstytucji francuskiej, ale nie ma legalnej definicji, oraz do ustawodawstwa francuskiego, które zakazuje manifestowania symboli religijnych w szkołach publicznych.

Trzecia sesja, której przewodniczył ks. dr hab. Leszek Adamowicz, prof. KUL, rozpoczęła się od wykładu przedstawiającego rozwiązania dotyczące obecności krzyża w przestrzeni publicznej stosowane na Litwie. Prelekcję na ten temat przygotowali ks. prof. dr Kazimieras Meilius oraz prof. dr Jonas Juskevicius (Mykolo Romerio Universitetas, Vilnius). Rozpoczynając od nawiązania do czasów, kiedy na Litwie ateizm był ideologią państwową, jako do czasów prześladowania kościoła, przedstawił formy, sytuacje i miejsca, którym najczęściej towarzyszy obecność krzyża. Szczególną uwagę poświęcił miejscu o nazwie „Wzgórze Krzyży”, które odgrywało w historii i nadal odgrywa ważną rolę dla społeczeństwa litewskiego. Następnie przedstawione zostały normy konstytucyjne odnoszące się do wolności religijnej zarówno w wymiarze indywidualnym, jak i wspólnotowym, omówiona została zasada rozdziału państwa od kościoła na Litwie, oraz konstytucyjne 
podejście do symboli religijnych. Prelegent powołał się na wyrok Trybunału Konstytucyjnego Litwy, który podkreślił znaczenie tradycji dla religii, a w konsekwencji brak możliwości zarówno tworzenia, jak i znoszenia tradycji przez jakikolwiek akt prawodawczy. Jako podsumowanie referatu poruszony został temat prawnej ochrony symboli religijnych, a także próba definiowania przestrzeni publicznej i znaczenia symboli religijnych.

Sprawę obecności krzyża w przestrzeni publicznej Rumunii omówił dr Laurenţiu Tănase (Universitatea din Bucureşti), rozpoczynając od podkreślenia doniosłości tego symbolu dla religii i kultury narodu rumuńskiego oraz jego powszechnej obecności w sferze publicznej. Prelegent wskazał cztery płaszczyzny, na jakich krzyż jest obecny: jako przedmiot liturgiczny, jako symbol historyczny, w wymiarze instytucjonalnym (obecność w instytucjach publicznych) oraz obecność krzyża w domenie prywatnej. Sprawa obecności krzyża w szkołach publicznych została przedstawiona na przykładzie sprawy Emila Moise przeciwko Ministrowi Edukacji.

Kolejna prelekcja, którą wygłosił prof. dr René Pahud de Mortanges (l’Université de Fribourg), poświęcona została obecności krzyża w przestrzeni publicznej Szwajcarii. Zdaniem autora referatu, obecność krzyża w przestrzeni publicznej w Szwajcarii jest tematem niekontrowersyjnym, gdyż krzyż jest obecny w wielu miejscach publicznych, takich jak dach budynku parlamentu szwajcarskiego, w górach, w wielu instytucjach publicznych, w tym naukowych, takich jak uniwersytet we Fryburgu. Prelegent bazował na dwóch sprawach dotyczących obecności krzyża w szkołach publicznych w kantonach Wallis i Lucerne, a także na orzecznictwie Sądu Najwyższego.

Obecność krzyża w sferze publicznej z perspektywy Irlandii przedstawił dr Brian Conway (National Uniwersity of Ireland Maynooth). Swoje rozważania rozpoczął od omówienia relacji państwo - kościół w Irlandii, następnie przedstawił obecność przejawów religijności w sferze edukacji, w instytucjach ochrony zdrowia, w armii irlandzkiej oraz w parlamencie. Przedstawił także kontekst społeczny i socjologiczny obecności krzyża w miejscach publicznych.

Ostatnie wystąpienie w sesji trzeciej, dotyczące sytuacji w Grecji, zaprezentował dr Konstantinos Papastathis (University of Luxembourg). Prelegent przedstawił grecki model powiązania państwa i kościoła, obejmując kontekst polityczny tematu i szczególną rolę Kościoła prawosławnego w Grecji. Jako podstawę prawną obecności symboli religijnych w przestrzeni publicznej wskazał prawo zwyczajowe i przepisy ogólne 
konstytucji Grecji. Przedstawił także orzeczenie Europejskiego Trybunału Praw Człowieka w sprawie Dimitras i inni przeciwko Grecji.

Po dokonaniu analizy rozwiązań stosowanych w niektórych państwach europejskich, sfinalizowaniem konferencji było omówienie obecności krzyża $\mathrm{w}$ przestrzeni publicznej z perspektywy polskiej, czemu została poświęcona czwarta sesja. Została ona podzielona na trzy referaty, zgodnie z konstytucyjnymi zasadami odnoszącymi się do symboli religijnych. Sesji czwartej przewodniczył ks. prof. dr hab. Józef Krukowski (KUL).

Pierwszy referat, pt. Obecność krzyża w przestrzeni publicznej a zasada bezstronności władz publicznych, został wygłoszony przez dra hab. Dariusza Dudka, prof. KUL. Wykład w znacznej części opierał się na analizie art. 25 ust. 2 Konstytucji Rzeczpospolitej Polskiej, ze szczególnym uwzględnieniem takich aspektów, jak: państwo, w którym przepis obowiązuje, podmiot, który jest adresatem normy prawnej, a także walor normatywny i konsekwencje prawne tego przepisu. Punktem wyjścia rozważań było przytoczenie historycznych przepisów gwarantujących wolność religijną na terenach ziem polskich, tj. Akt Konfederacji Warszawskiej, Konstytucja 3-go Maja, Konstytucja Marcowa oraz obecnie obowiązującej Konstytucji z 1997 r. Istotną częścią było także wyjaśnienie pojęcia bezstronności światopoglądowej władz publicznych, a kulminacją rozważań było naświetlenie sporu dotyczącego obecności krzyża w sali posiedzeń Sejmu.

Obecność krzyża w przestrzeni publicznej a wolność sumienia i religiito drugi w tej sesji referat, który został wygłoszony przez ks. dra hab. Piotra Stanisza, prof. KUL. Prelegent dokonał szczegółowej analizy przepisu art. 53 ust. 2 Konstytucji RP, z uwzględnieniem prawa do uzewnętrzniania przekonań religijnych, które mieści w sobie także prawo do uzewnętrzniania przekonań $\mathrm{z}$ wykorzystaniem symboli religijnych. W ramach rozważań została podjęta m.in. kwestia dopuszczalności ograniczenia wolności uzewnętrzniania religii, $\mathrm{w}$ tym $\mathrm{z}$ wykorzystaniem symboli religijnych. Znaczącym elementem było wyjaśnienie negatywnego aspektu wolności religijnej i odpowiedź na kluczowe pytanie, dotyczące kwestii naruszenia tej sfery wolności religijnej przez obecność krzyża w przestrzeni publicznej. Zostało przybliżone także aktualne orzecznictwo w tej sprawie.

Trzeci i zarazem ostatni referat, pt. Obecność krzyża w przestrzeni publicznej a prawo rodziców do wychowania dzieci zgodnie ze swoimi przekonaniami, wygłosił dr hab. Paweł Sobczyk, prof. UO. Prelegent przedstawił prawo rodziców do wychowania dzieci zgodnie z przekonaniami, 
którego źródłem jest godność człowieka, jako aspekt pomijany w dyskusji na temat obecności krzyża w sferze publicznej, głównie w szkołach publicznych. Referat opierał się głównie na analizie przepisów art. 48 i 53 ust. 3 Konstytucji RP, a także § 12 rozporządzenia Ministra Edukacji Narodowej z dnia 14 kwietnia 1992 r. w sprawie warunków i sposobu organizowania nauki religii w publicznych przedszkolach i szkołach, stanowiącego podstawę umieszczania krucyfiksu na ścianach sal lekcyjnych w szkołach publicznych. Ponadto przedstawiał obecność krzyża w szkołach publicznych jako realizację zewnętrznego aspektu prawa rodziców do wychowania dzieci zgodnie z własnymi przekonaniami.

Zorganizowana konferencja odegrała bardzo doniosłą rolę w podniesieniu świadomości na temat obecności symboli religijnych, głównie krzyża, w przestrzeni publicznej poszczególnych państw europejskich. Uczestnicy mieli możliwość zapoznania się nie tylko z rozwiązaniami prawnymi czy orzecznictwem sądów krajowych oraz Europejskiego Trybunału Praw Człowieka w tej kwestii, ale również mogli zaznajomić się z aspektem socjologicznym tego zagadnienia. Wygłoszone referaty pozwoliły nabrać nowego spojrzenia na prowadzoną debatę związaną z obecnością krzyża w miejscach publicznych, jak również ułatwiły zrozumienie rozwiązań przyjmowanych w innych krajach. Spotkanie było także okazją do dyskusji na tematy szczególnie nurtujące uczestników konferencji.

mgr Katarzyna Starzecka Wydziat Prawa, Prawa Kanonicznego i Administracji Katolicki Uniwersytet Lubelski Jana Pawła II 